\title{
The Effect of Oil Price on China's Grain Prices: a VAR model
}

\author{
Jingye $\mathbf{L i}^{1}$
}

\begin{abstract}
In recent years, the simultaneous trend of crude oil prices and agricultural prices has gained numerous attention of policy makers and market participants. This paper uses a vector autoregression model to examine the impact of the international crude oil prices on China's grain prices including wheat, maize, soybean and rice during the period from June 2004 to December 2018. Empirical results indicates that international crude oil prices have a positive and significant impact on China's grain prices. The response of grain prices would gradually decline to zero after reaching its maximum. Among these grain prices, the response of maize and soybean prices to crude oil prices is stronger than the rice and wheat prices. The error variance decomposition results show that most of the volatility in all price variables can be explained by own shocks, even though the fluctuation of grain prices are all affected by crude oil prices.
\end{abstract}

JEL classification numbers: $\mathrm{O} 13$

Keywords: Oil prices, Grain prices, VAR, Variance decomposition.

${ }^{1}$ Xinjiang University, School of Economics and Management.

Article Info: Received: February 6, 2021. Revised: February 19, 2021.

Published online: February 22, 2021. 


\section{Introduction}

Agricultural prices have always been the focus of policy makers and market participants as its volatility poses an important threat to agriculture safety, and even breaks the economic balance of almost all countries especially developing countries (Ma et al. 2015). In order to avoid food crisis, a large number of agricultural policy documents in China was published to benefits agricultural commodities and draws the balance between supply and demand. However, recent studies concluded that agricultural prices were not only guided by the basic factors related to supply and demand (Prakash et al.2011), but also can be explained by many other factors, such as climatic changes, monetary policies and macroeconomic environment, which has obtained widespread discussion. Therefore, it is meaningful to explore and understand the potential factors affecting grain prices.

In the ongoing debate on the sources of volatility of agricultural prices, a sea of the literature turned its attention to the impact of oil prices based on the synchronous trend of oil prices and agricultural prices. On the one side, some scholars believe that oil prices influence the evolution of agricultural prices. For example, Hanson et al. (1993) found that agriculture generally loses from oil prices shock by using the CGE (Computable General Equilibrium) model. Baffes (2007) examined the impact of crude oil prices on the prices of 35 internationally traded primary commodities and found the pass-through of crude oil price to non-energy index. Chen (2010) investigated the relationship between crude oil prices and global grain prices including corn, soybean, and wheat. He found that each grain price was significantly influenced by the changes of crude oil prices and other grain prices. Ji (2012) concluded that the crude oil market had some significant volatility spillover effects on non-energy commodity markets. Furthermore, Gozor (2014) analyzed the systematic interrelationship between the world oil prices and 27 agricultural prices using monthly data, and attempted to link the global financial markets with the agricultural markets. Their overall results point out that oil prices have a unidirectional positive impact all agricultural commodity price. More recently, Dillon (2016) also states that global oil prices affect grain prices, but primarily through transportation in east Africa.

Similar to commodity spot markets, futures price also show similar influence from the oil market. For example, Natanelov (2011) developed a comprehensive study focusing on the interaction between crude oil futures markets and other nine commodity futures markets. By using monthly futures prices, he observed strong linkages between crude oil and these markets. Koirala (2015) used a new econometric method (copula) to investigate the dependence between agricultural commodity futures prices and energy futures prices, and the overall results revealed that they were highly correlated showing a positive and significant relationship. Additionally, Wei (2016) investigated the relationship between crude oil prices and grain futures for daily soybeans, wheat and corn data. He found that grain futures prices were significantly impacted by the crude oil futures prices.

On the other side, agricultural prices are not always impacted in a significant way 
by oil prices. Kaltalioglu (2011) measured the volatility spillover between world oil, grain and agricultural raw material prices, and he found was that there was not identified any volatility spillover from the oil returns to the grain returns. Kapusuzoglu (2015) analyzed the relationships between world oil prices and agricultural prices (wheat, corn and soybeans). Employing Johansen co-integration tests results, he exposed that there were no long-run relationships between agricultural commodity prices and world oil prices. Ma et al. (2015) examined the long-run and short-run influence caused by the world crude oil prices and RMB against the US dollar exchange rate on the five individual agricultural commodity prices including soybean, maize, wheat, colza oil and japonica rice in China.

Another strand of literature divided the data into different time periods to explore the relationship between oil prices and agricultural prices. Campiche (2007) selected weekly price data from 2003 to 2007 for corn, soybean oil, world sugar and crude oil, dividing the period into two time periods, namely 2003-2005 and 20062007. The Johansen cointegration tests revealed no cointegrating relationships during the first period. However, corn and soybean prices were cointegrated with crude oil prices during the second period. Ciaian (2011) segmented the price series (including world crude oil price and nine agricultural commodities) for the period 1993-2010 into three equally sampled sub-periods. According to the empirical analysis, there was no cointegration relationships in the first period (1992-1998), while just corn and soybeans were cointegrated with crude oil prices in the second period (1999-2004), and nine agricultural commodities were cointegrated with crude oil prices in the third period (2005-2010).

The purpose of this paper is to empirically quantify the impact of international crude oil prices on China's agricultural especially grain prices including wheat, maize, soybean and rice. To the best of our knowledge, limited research has investigated the association of oil price and Chinese food price. We applied a vector autoregression (VAR) model to examine how oil price affect the food price. Then, an impulse response and variance decomposition was used to examine the long term volatility spillover of oil price on grain price.

The remainder of this paper is organized as follows. Section 2 introduces the econometric methodology used in this study. Data and preliminary analysis are exhibited in Section 3. Section 4 demonstrates the reaction of agricultural prices on crude oil prices. Conclusions and discussion are debated in Section 5.

\section{Methodological design}

To analyze the response of grain price on oil price, we construct a basic m-variable VAR model, which can be defined as follows:

$$
A y_{t}=B_{1} y_{t-1}+B_{2} y_{t-2}+\cdots+B_{s} y_{t-s}+\varepsilon_{t}
$$

Where $y_{t}$ represents a $5 \times 1$ vector of oil price, and grain prices returns series at time t. A and $B_{s}$ are a $5 \times 5$ matrix of coefficient relating series changes at lagged 
s period to current changes, and $\varepsilon_{t}$ a $5 \times 1$ vector of errors. Rewrite the equation (1) as representation vector moving average(VMA), that is:

$$
y_{t}=\mu+\sum_{i=1}^{\propto} \varphi_{i}+\varepsilon_{t-1}
$$

Where $\varphi_{i}$ is a $5 \times 5$ matrix including element coefficient of $\varepsilon_{t-1}$ with respect to shocks of $\varepsilon_{t-s}$ on price variables. It means that the element coefficients are impulse response of dependent variable to the shock from lagged explanatory variables' error term. Additionally, based on the equation (1), we could also obtain the conditional expectation of $\hat{y}_{t}$, which is $A+B_{1} y_{t-1}+B_{2} y_{t-2}+\cdots+B_{s} y_{t-s}$, and the forecast error is $e_{t}$. The n-step-ahead forecast error is:

$$
\hat{y}_{t}=e_{t+n}+A_{1} Y_{t+n-1}+A_{1}^{2} Y_{t+n-2}+\cdots+A_{1}^{n-1} Y_{t+1}=\sum_{i-0}^{n-1} A_{1}^{i} e_{t+n-i}
$$

Equation (3) provide the information to explain the forecast error in different forms. Therefore, the forecast error variance could be decomposed through each one of the shocks.

\section{Data and preliminary analysis}

This paper uses monthly data spanning from June 2004 to December 2018 for the international crude oil prices and China's grain prices. The source of data for the international oil prices is West Texas Intermediate. Given the reporting indifferent currencies, we express oil prices in Chinese currency through the corresponding exchange rate. Grain prices are obtained from Wind database covering the price index of wheat, maize, soybean and rice. According to Wei and Chen (2016), we convert the price series into return series.

Table 1: Unit root test of price return series

\begin{tabular}{|l|c|c|c|c|}
\hline & \multicolumn{2}{|c|}{ Intercept } & \multicolumn{2}{c|}{ Intercept and trend } \\
\hline & test statistics & P-value & test statistics & P-value \\
\hline Crude oil & -8.971 & 0.000 & -8.992 & 0.000 \\
\hline Wheat & -9.106 & 0.000 & -9.160 & 0.000 \\
\hline Maize & -7.387 & 0.000 & -7.435 & 0.000 \\
\hline Soybean & -4.952 & 0.000 & -5.023 & 0.000 \\
\hline Rice & -8.908 & 0.000 & -9.001 & 0.000 \\
\hline
\end{tabular}


To avoid spurious regression, this paper performs some unit root tests. We uses the Augmented Dickey-Fuller (ADF) test to verify the stationary of these price return series. Table 1 presents the results for ADF unit tests. All price return series reject the null hypothesis of containing at least one unit root indicating that these series are stationary, regardless of whether the intercept or the trend, intercept is included.

\section{Empirical results and discussion}

\subsection{Empirical result}

Based on the VAR model, impulse responses can be computed at different lag period through the estimated coefficient. We need to firstly determine the optimal lag period of model. Given the series sample size of $n=175$, eight lags will be the maximum number that can be put in the VAR to obtain the efficient degrees of freedom. In addition, according to the AIC, FPE, HQ and SC criterion given in Appendix A, we set the optimal lag period as one.

We then select the lag12 months to analyze the change and duration of impulse responses. Figure 1 shows the results of the impulse response for the four grain price on crude oil price. The initial response of maize, rice, soybean and wheat to oil price are positive and significant, especially for soybean and maize. The response of maize and rice reach the maximum value at second period, and then gradually decline to zero. The response of soybean and wheat price keep continuous downward trend after obtaining the shock at first period. this means that the response of all grain prices on crude oil price is more significant in the short term than that in the medium and long term. This is consistent with economic theory and the conclusion by Wei and Chen (2016), as a stable system would cause any shock to gradually decline to zero while an unstable one would lead to an explosive trend. 

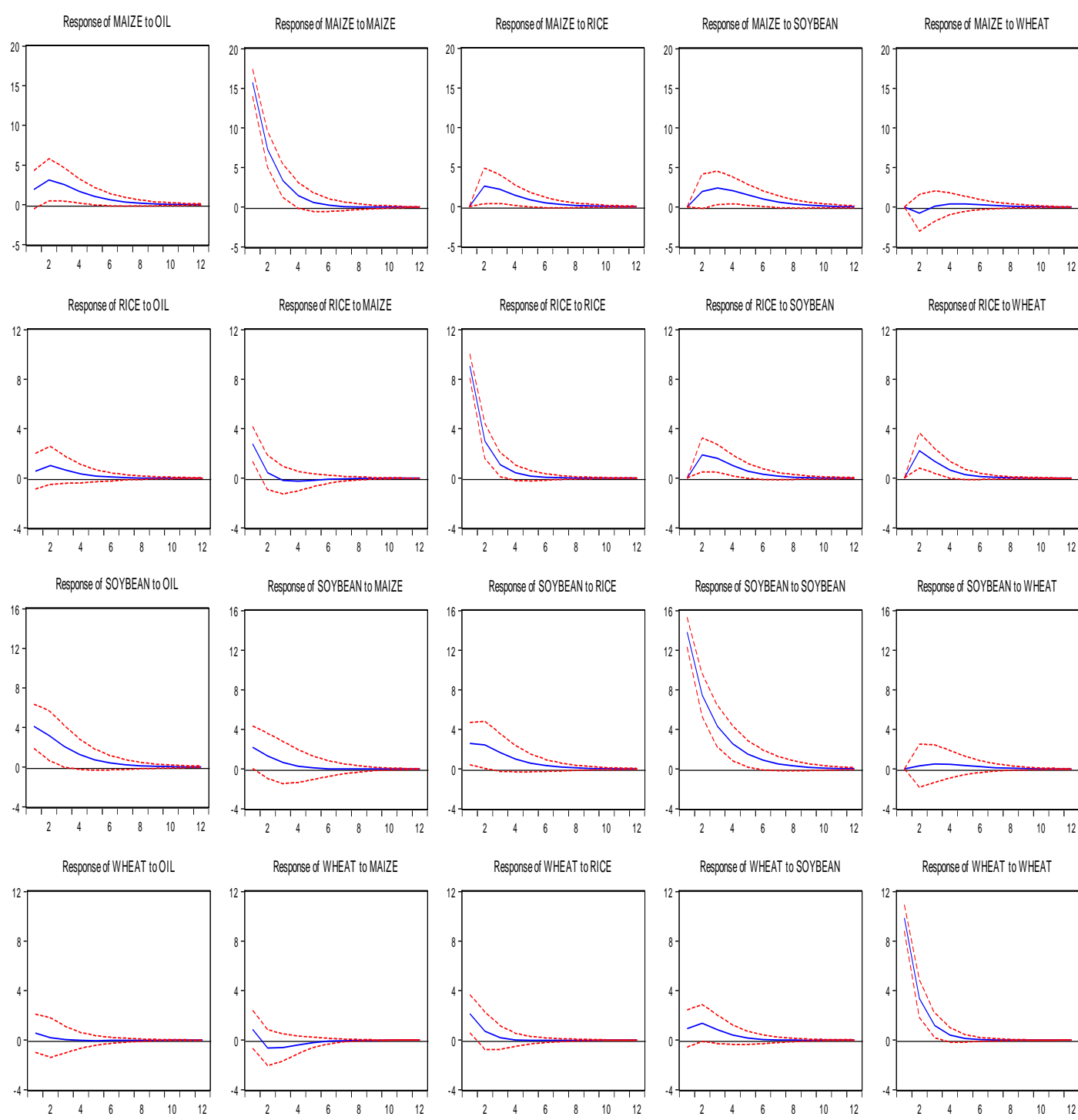

Figure 1: Impulse response of grain prices on crude oil prices.

In addition, it is noticeable that four grain prices also positively respond to other grain prices. For example, the increase of rice price would also induce a higher maize price, soybean price and wheat price (Figure1, Column 3), and all these response would also gradually decline to zero.

We further conduct an error variance decomposition to further analyze the dynamic volatility spillovers of crude oil prices on China's grain prices. Table 3 presents the result of variance decomposition between crude oil prices and grain prices. The results show that most of the volatility in all price variables can be explained by own shocks, and the shocks will be weakened with the increase of forecast period. At the same time, the fluctuation of grain prices are all affected by crude oil prices. For example, During the forecast period from first month to Twelfth month, 
volatility spillover from crude oil prices range between $0.0 \%$ (wheat) to $10.16 \%$ (soybean). Based on the comparison of different grain prices, as same as the results of impulse response, oil prices have a greater impact on soybean and maize prices than rice and wheat prices. Those from crude oil prices to soybean prices range between $1.83 \%$ to $10.16 \%$, and to maize prices range between $1.44 \%$ to $6.56 \%$. however, the spillovers to wheat and rice prices are less than $1.7 \%$.

Table 2 : The variance decomposition

\begin{tabular}{|c|c|c|c|c|c|c|c|c|c|c|}
\hline $\begin{array}{c}\text { Forecast } \\
\text { period }\end{array}$ & Oil & Wheat & Maize & Soybean & Rice & Oil & Wheat & Maize & Soybean & Rice \\
\hline 1 & 0.29 & 99.71 & 0.00 & 0.00 & 0.00 & 1.44 & 0.72 & 97.84 & 0 & 0 \\
\hline 3 & 0.28 & 97.19 & 1.17 & 1.30 & 0.06 & 5.61 & 0.95 & 87.37 & 3.77 & 2.30 \\
\hline 6 & 0.29 & 96.87 & 1.35 & 1.42 & 0.08 & 6.52 & 1.41 & 83.65 & 5.90 & 2.52 \\
\hline 12 & 0.29 & 96.86 & 1.35 & 1.42 & 0.08 & 6.56 & 1.44 & 83.41 & 6.07 & 2.52 \\
\hline \multicolumn{8}{|c|}{ Soybean } \\
\cline { 2 - 12 } & Oil & Wheat & Maize & Soybean & Rice & Oil & Wheat & Maize & Soybean & Rice \\
\hline 1 & 7.72 & 1.83 & 1.91 & 88.54 & 0.00 & 0.34 & 5.02 & 7.47 & 2.25 & 84.92 \\
\hline 3 & 9.85 & 2.61 & 1.83 & 85.26 & 0.44 & 1.55 & 14.22 & 5.99 & 7.41 & 70.82 \\
\hline 6 & 10.16 & 2.92 & 1.76 & 84.65 & 0.50 & 1.65 & 14.60 & 6.00 & 8.40 & 69.34 \\
\hline 12 & 10.16 & 2.94 & 1.76 & 84.63 & 0.50 & 1.66 & 14.60 & 6.00 & 8.43 & 69.32 \\
\hline
\end{tabular}

\subsection{Discussion for empirical result}

Based on the impulse response and error variance, We confirm that the international crude oil prices plays an important role on the volatility China's grain prices. how does the international crude oil prices influence grain prices? Why crude oil price has stronger impact on soybean and maize price than rice and wheat prices? The production costs, biofuel and transportation might be three mainly factors.

Firstly, higher input costs can directly higher price. Crude oil is the main raw material for agricultural production materials such as inorganic fertilizers, pesticides and films, and crude oil products such as diesel oil are the main fuel of tractors and pumps. According to Huang (2009), the use of energy accounts for $30 \%$ of the total cost of agricultural production in China, which means that energy prices increases by $10 \%$, and agricultural production costs will increase by about $3 \%$.

Secondly, biofuel is an important potential factor. After 2006, a rapid rising in crude oil prices increased the demand for biofuel such as bioethanol and biodiesel Mainly made by agricultural products such as maize and soybeans. This would increase the derived demand for maize, soybean, and then raise their prices. In addition, as Wei and Chen (2016) discussed, because of limited endowment of planted acreage, other foods is being used as substitutes for maize and soybean, the wheat and rice prices is also be stimulated.

The third factor is transportation costs. More specifically, the production and 
consumption of agricultural products is done in different areas of China, thus while the production is performed in some specific regions, the consumption might be registered in different regions. As such, in order to achieve the sale objectives of different products, transportation to various places needs to be considered, issue which raises additional operational costs and influences significantly agricultural prices.

\section{Conclusion}

This study investigates the impact of international crude oil prices (West Texas Intermediate) on China's grain prices (wheat, maize, soybean and soybean) over the period June 2004 - December 2018. After ADF test and determining the optimal lag period, we use VAR model to analyze the impulse responses of grain prices on crude oil prices, and measure the volatility spillovers on grain prices.

Empirical results indicate that international crude oil prices has a significant and positive impact on China's grain prices. The response of grain prices would gradually decline to zero after reaching its maximum. Among these grain prices, the response of maize and soybean prices to crude oil prices is stronger than the rice and wheat prices. The error variance decomposition results show that most of the volatility in all price variables can be explained by own shocks, even though the fluctuation of grain prices are all affected by crude oil prices.

Our implication is that to weaken the impact of crude oil prices on the prices of agricultural products to safeguard national food security, researchers in related fields need to research new technologies unremittingly for biomass energy and develop non-food biomass energy such as cassava, sweet potato and sorgo stems. In addition, in order to reduce production cost, it is an effective measure which we should take into consideration to weaken the excessive dependence of agricultural production on high-energy production factors such as fertilizers and pesticides.

\section{ACKNOWLEDGEMENTS.}

The authors declare that there is no conflicts of interest. 


\section{References}

[1] Ma, Z.W., Rui, X. and Dong, X.C. (2015). World oil prices and agricultural commodity prices: the evidence from China. Agricultural Economics. 61(12):564-576.

[2] Prakash, A., Gilbert, C.L. and Prakash A. (2011). Rising vulnerability in the global food system: beyond market fundamentals. Safeguarding Food Security in Volatile Global Markets. 42-66.

[3] Hanson, K., Robinson, S. and Schluter, G. (1993). Sectoral Effects of a World Oil Price Shock: Economy wide Linkages to the Agricultural Sector. Journal of Agricultural \& Resource Economics.18(1):96-116.

[4] Baffes, J. (2007). Oil spills on other commodities. Resources Policy. 32(3):126-134.

[5] Chen, S.T., Kuo, H.I. and Chen, C.C. (2010). Modeling the relationship between the oil price and global food prices. Applied Energy.87(8):2517-2525.

[6] Ji, Q. and Fan, Y. (2012). How does oil price volatility affect non-energy commodity markets? Applied Energy.89(1):273-280.

[7] Gozgor,G. and Kablamaci, B. (2014). The linkage between oil and agricultural commodity prices in the light of the perceived global risk. Mpra Paper. 60(60):332-342.

[8] Dillon, B. M. and Barrett, C. B. (2016). Global oil prices and local food prices: Evidence from east Africa. American Journal of Agricultural Economics, 98(1), 154-171.

[9] Natanelov, V., Alam, M. J., Mckenzie, A. M, et al. (2011). Is there comovement of agricultural commodities futures prices and crude oil? Energy Policy. 39(9):4971-4984.

[10] Koirala, K., H., Mishra A. K., D'Antoni, J. M. et al. Energy prices and agricultural commodity prices: Testing correlation using copulas method. Energy, 2015, 81: 430-436.

[11] Wei, C.C. and Chen, S.M. (2016). Examining the relationship of crude oil future price return and agricultural future price return in US. International Journal of Energy Economics \& Policy. 6(1):58-64.

[12] Kaltalioglu, M. and Soytas, U. (2011). Volatility Spillover from Oil to Food and Agricultural Raw Material Markets. Modern Economy.2(2):71-76.

[13] Kapusuzoglu, A. and Ulusoy, M.K. (2015). The interactions between agricultural commodity and oil prices: an empirical analysis. Agricultural Economics. 61(9):410-421.

[14] Campiche, J. L., Bryant, H. L., Richardson, J. W. and Outlaw, J. L. (2007). Examining the evolving correspondence between petroleum prices and agricultural commodity prices (No. 381-2016-22070).

[15] Ciaian, P. and Kancs, D. (2011). Interdependencies in the energy-bioenergyfood price systems: A cointegration analysis. Resource \& Energy Economics. 33(1):326-348. 
[16] Wei, C. C., and Chen, S. M. (2016). Examining the relationship of crude oil future price return and agricultural future price return in US. International Journal of Energy Economics and Policy. 6(1).

[17] Huang, J.K., Yang, J., Qiu, H.G., and Xu, Z.G. (2009). The current food prices skyrocketed: the main reason and the future trend. Management World. (1):7278 (in Chinese).

[18] Baffes, J. and Haniotis, T. (2016). What explains agricultural price movements?. Journal of Agricultural Economics, 67(3), 706-721.

Appendix A the selection of optimal lags

\begin{tabular}{|c|c|c|c|c|c|c|}
\hline Lag & Log L & LR & FPE & AIC & SC & HQ \\
\hline $\mathbf{0}$ & -3635.778 & NA & $7.72 \mathrm{e}+12$ & 43.86479 & 43.95853 & 43.90284 \\
\hline $\mathbf{1}$ & -3543.952 & 177.0141 & $3.45 \mathrm{e}+12^{*}$ & $43.05966^{*}$ & $43.62207^{*}$ & $43.28795^{*}$ \\
\hline $\mathbf{2}$ & -3527.746 & 30.26405 & $3.84 \mathrm{e}+12$ & 43.16561 & 44.19669 & 43.58414 \\
\hline $\mathbf{3}$ & -3514.361 & 24.18939 & $4.43 \mathrm{e}+12$ & 43.30556 & 44.80531 & 43.91432 \\
\hline $\mathbf{4}$ & -3486.959 & 47.87187 & $4.32 \mathrm{e}+12$ & 43.27661 & 45.24504 & 44.07561 \\
\hline $\mathbf{5}$ & -3465.035 & 36.97945 & $4.51 \mathrm{e}+12$ & 43.31368 & 45.75077 & 44.30291 \\
\hline $\mathbf{6}$ & -3448.610 & 26.71531 & $5.05 \mathrm{e}+12$ & 43.41699 & 46.32276 & 44.59646 \\
\hline $\mathbf{7}$ & -3418.670 & 46.89338 & $4.82 \mathrm{e}+12$ & 43.35748 & 46.73192 & 44.72719 \\
\hline $\mathbf{8}$ & -3392.502 & $39.41040^{*}$ & $4.83 \mathrm{e}+12$ & 43.34340 & 47.18651 & 44.90334 \\
\hline
\end{tabular}

